\title{
Identification, purification, and cloning of a polypeptide (PRTF/GRM) that binds to mating-specific promoter elements in yeast
}

\author{
Gustav Ammerer ${ }^{1}$ \\ MRC Laboratory of Molecular Biology, Cambridge CB2 2QH UK
}

In yeast the $\alpha$-specific regulators, $\alpha 1$ and $\alpha 2$ have been proposed to be DNA-binding proteins, both of which have to interact with an additional factor called PRTF or GRM, respectively, to exert their biological functions. Although the cis-acting sequence requirements for $\alpha 1$ and $\alpha 2$ are different, their target sequences share a common motif. PRTF or GRM is thought to act via this common DNA sequence; therefore, it has been suggested that they represent the same factor. I purified a protein that binds to this common promoter element by DNA affinity chromatography. The purified protein is able to recruit the $\alpha$-specific activator $\alpha 1$ to its binding sites, suggesting that it is indeed PRTF. Further evidence is presented to show that PRTF and GRM are the same protein and that PRTF plays a role in the activation of a-specific genes. Specific antibodies to the purified protein were obtained. They identify the protein as a component of DNA-protein complexes that formed with cell-type-specific promoter sequences. Using these antibodies, the gene encoding the protein was cloned from a yeast $\lambda$ gt 11 expression library. The DNA sequence established that the gene encoding PRTF/ GRM is identical with a previously described gene, FUN80 (essential factor of unknown function) or MCM1 (minichromosome maintenance). Sequence comparison showed further that PRTF/GRM shares similarities with a repressor from yeast, ARGRI, and the mammalian transcription factor SRF.

[Key Words: Yeast; cell-type-specific transcription; PRTF; GRM; MCM1 gene]

Received June 8, 1989; revised version accepted November 7, 1989.

At least two kinds of interactions are important for the establishment of combinatorial transcriptional control in a eukaryotic organism: the recognition of specific promoter sequences by DNA-binding domains and protein-protein interactions between different regulatory factors. Defining the nature of these interactions poses an important biological problem, as subtle differences in their parameters may determine whether a gene is turned on or off. The promoters of mating-specific genes in the yeast Saccharomyces cerevisiae seem an excellent model system for studying some of the principles of combinatorial control. Even though these promoters share several cis-acting elements and trans-acting factors, their expression is highly restricted to certain cell types. Yeast cell types are operationally defined by a cell's mating behavior. Normally, two haploid cells of opposite mating type (called a and $\alpha$ ) conjugate to form a diploid zygote, which produces nonmating progeny. As a precondition for cellular fusion, cells have to communicate with each other and do so via a set of cell-type-spe-

1Current addresses: Institut für Allgemeine Biochemie, University of
Vienna, A1090 Vienna, Austria; Institute of Molecular Pathology, A1030 Vienna, Austria. cific pheromones and their respective receptors. The presence or absence of the MAT $\alpha$ allele at the matingtype locus determines whether an $\alpha$ - or a-specific set of receptor and pheromone genes will be transcribed (Strathern et al. 1981), which, in turn, will lead to $\alpha$ or a-specific mating behavior (Bender and Sprague 1986; Nakayama et al. 1987).

$M A T \alpha$ encodes two regulatory proteins, $\alpha 1$ and $\alpha 2$, both of which act at the level of protein-DNA interactions. $\alpha 1$ is a specific inducer of $\alpha$-specific promoters (e.g., STE3, $M F \alpha 1$ and $M F \alpha 2$ ) whereas $\alpha 2$ is a repressor of a-specific functions (e.g., STE2, MFa1 and MFa2, STE6, $B A R 1$ ). It has been shown that $\alpha 2$ can interact directly with the promoter via a 30 -bp motif common to all aspecific promoters (Johnson and Herskowitz 1985). Although, conceptually, it is not necessary to assume that a- and $\alpha$-specific promoters have anything in common with each other, a surprising structural relationship between these promoters has been discovered. A palindromic motif with the consensus TTTCCTAATTAGGAAA (called P or PAL box) is intimately involved in promoter function of both sets of cell-type-specific genes. In a-specific genes this sequence forms the central part of the $\alpha 2$-binding site (Kronstad et al. 1987). Using a 
deletion mutation within the site, Keleher et al. (1988) were able to show that, in vivo, this motif is essential for $\alpha 2$-dependent repression. They also observed that the dissociation rate of an $\alpha 2-D N A$ complex decreases substantially in the presence of a cell-type-independent factor that binds to the palindrome. They called this factor GRM for general regulator of mating.

In $\alpha$-specific genes, one end of the palindrome diverges slightly from the consensus (further indicated as $\mathrm{P}^{\prime}$ ) and is replaced by another sequence element called the $Q$ box (Inokuchi et al. 1987; Jarvis et al. 1988; Flessel et al. 1989|. Promoter fragments that contain either sequence motif ( $P$ or $P^{\prime} Q$ box) are sufficient to serve as upstream activation sequences (UAS) in an appropriate in vivo assay. They are also able to form a specific DNA-protein complex in an in vitro assay (Bender and Sprague 1987; this paper). However, at least one $\alpha$-specific sequence, the $\mathrm{P}^{\prime} \mathrm{Q}$ element of the a-pheromone receptor gene (STE3), seemed to recruit this binding activity only in conjunction with the $\alpha 1$ protein (Bender and Sprague 1987). The DNA-binding protein that can form a complex with $\alpha 1$, but is expressed independently of the particular cell type, has been called PRTF for pheromone receptor transcription factor. $\alpha 1$, itself, cannot form a stable complex with DNA but does so only with the cooperation of PRTF (Tan et al. 1988).

In summary, these observations led to the model presented in Figure 1. Because the factors responsible for the functionally defined PRTF and GRM activity bind to the same target sequence, it has been proposed that they are represented by the same protein. Accordingly, $\alpha$-specific promoters are transcribed only in $\alpha$ cells, as the physical interaction between $\alpha 1$ and PRTF/GRM is required for the formation of a stable complex at the $\alpha$-specific $\mathrm{P}^{\prime} \mathrm{Q}$ elements. In contrast, PRTF/GRM interacts

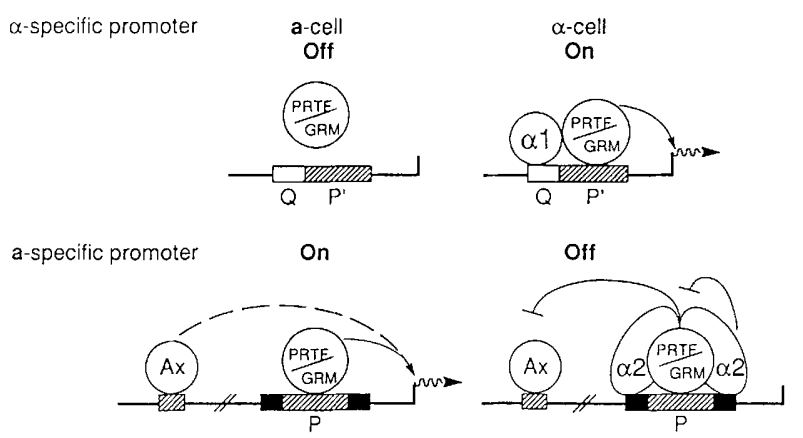

Figure 1. Model for transcriptional regulation of cell-type-specific genes. GRM and PRTF represent the same protein complex interacting with different regulatory proteins in a different DNA sequence context. PRTF/GRM binds at a-specific promoters to the central part of the $\alpha 2$ operator. Depending on the cell type, it participates among other factors $(A X)$ in the activation of the promoter or acts as repressor in a complex with $\alpha 2$. In the absence of $\alpha 1$, PRTF/GRM cannot bind efficiently to $\alpha$ specific promoter elements; however, a complex between $\alpha 1$ and PRTF/GRM binds tightly enough to activate transcription of $\alpha$-specific genes. with a-specific promoters in all cell types. In this case, PRTF/GRM participates in the formation of an active transcription complex unless its physical interaction with $\alpha 2$ interferes with such requirements.

Two questions are of immediate importance for the further development of this model for mating-type control: What is the exact structural relationship between PRTF and GRM, and what proteins are involved in the formation of these two binding activities? To answer these questions, the major goal of this work was to purify and characterize the protein or proteins associated with PRTF and GRM activity, with the intent to clone and sequence the corresponding gene(s). Concurrent with these experiments, I was able to define more precisely the cis-acting requirements necessary for celltype-specific activation.

\section{Results}

\section{Characterization of $\alpha$-specific activating sequences}

To assure that the sequences selected for purification and characterization of P-box-binding proteins were also biologically significant, I tested their ability to activate a heterologous promoter in vivo. In yeast, such tests are usually done with a plasmid like pLG $\Delta 178$, which contains a disabled CYC1 promoter linked to the $1 a c Z$ gene as a reporter function (Guarente and Hoar 1984). For these experiments I used two synthetic fragments, each of which included one of the two $P^{\prime} Q$ elements of the $M F \alpha 1$ promoter (the proximal element is called block A, and the more distal element, block B, according to Bender and Sprague 1987). These DNA sequences, which encompass 21 and 23 bp of the promoter, are shown in Figure 2A. Derivatives of plasmid pLG $\Delta 178$, which contain a $M F \alpha 1$ block $\mathrm{A}(M F \alpha 1-\mathrm{A})$ or block $\mathrm{B}(M F \alpha 1-\mathrm{B})$ sequence, lead to the synthesis of $\beta$-galactosidase when introduced into $\alpha$ cells. When the same plasmids were transformed into an isogenic a strain, the levels of enzymic activity were 10 - to 20 -fold lower or only slightly above background (Fig. 2B). In the $M F \alpha 1$ promoter, an additional sequence with strong homology to the $\mathrm{P}$ box can be seen at a position -464 to -478 from the initiation codon (called block C; Flessel et al. 1989). A 19-bp oligonucleotide was synthesized, which includes this more precise palindromic motif, with the exception that 1 nucleotide was changed to give a better fit with the consensus sequence $\left(M F \alpha 1-C^{\prime}\right)$. $\beta$-Galactosidase levels derived from a plasmid carrying this sequence appear to be independent of the cell type $(\mathbf{a}, \alpha$, or $\mathbf{a} / \alpha)$ of the transformant (Fig. 2B). These results essentially confirm those reported by Jarvis et al. (1988), implying that $\alpha \mathbf{l}$ cannot be the only trans-acting factor interacting with the P-box sequence motif. Additionally, they confine the sequence requirements for $\alpha 1$ dependence in vivo to just 7 bp of the $Q$ box. What also appears quite interesting from the sequence comparison between block $\mathrm{A}$ and block $\mathrm{C}^{\prime}$ is that, at most, three nucleotide changes are necessary to convert an essentially nonspecific promoter element into a highly $\alpha 1$-specific one. 


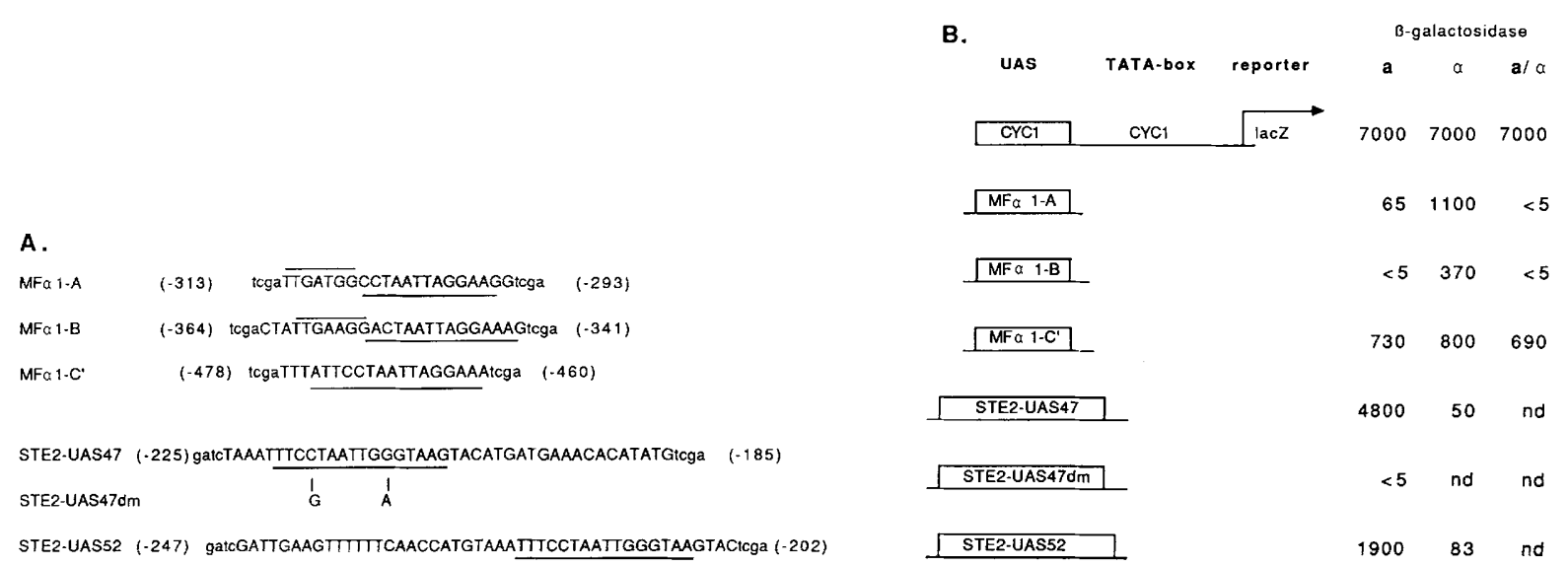

Figure 2. Characterization of different cell-type-specific elements. $(A)$ DNA sequence of the different oligonucleotides used for in vivo and in vitro experiments. The P- and Q-box consensus sequences are underlined or overlined, respectively. $(B)$ Results obtained with CYC1-lacZ fusion vectors. Units are defined as described by Breeden and Nasmyth (1987).

\section{Characterization of an a-specific activation sequence}

The role of the TTTCCTAATTAGGAAA motif in the activation of a-specific promoters has been ambiguous. On the one hand, deletion analysis suggested that the $\alpha 2$-binding motif of an a-specific promoter (BAR1) is also important for transcriptional activation (Kronstadt et al. 1987). On the other hand, it was reported that this motif, as isolated from the STE6 promoter (Wilson and Herskowitz 1986), was not sufficient to function as a UAS (Johnson and Herskowitz 1985). In initial experiments using the STE2 gene, I found that a 97-bp fragment of the STE2 upstream sequence that contained the $\mathrm{P}$ box is able to promote transcription of a reporter gene at relatively high levels [Errede and Ammerer (1989); the same sequence was described by Miller et al. (1985) as sufficient to mediate $\alpha 2$ repression]. Additionally, transcriptional activation was still dependent on the genetically identified trans-acting factors (e.g. STE12 and STE4; data not shown) that are crucial for the transcription of the STE2 gene, itself (Hartig et al. 1986; Fields et al. 1988). To narrow down the sequences important for activation, two fragments of 47 and $52 \mathrm{bp}$ overlapping most of the STE2- $\alpha 2$-binding site were synthesized (Fig. 2A). They extend from the $\alpha 2$-binding site into either $5^{\prime}$ - or $3^{\prime}$ flanking sequences of the STE2 promoter (Nakayama et al. 1985). Both fragments strongly activate the CYC1 promoter and still mimic the cell-type-specific regulation of the STE2 promoter (Fig. 2B). To discover whether the P-box motif plays an essential role in the activation function of these artificial a-specific promoters, I changed two nucleotides in the 47-bp fragment. The mutations affect two nucleotides that are invariable among the different binding sites. The fragment was tested for its ability to activate the CYC1-lacZ indicator gene and found to be completely inactive (Fig. 2B). It therefore appears that, at least in the STE2 promoter, the $\mathrm{P}$ box contributes to the activation of the gene.

\section{Properties of a P-box-binding activity}

A gel retardation assay (Fried and Crothers 1981; Garner and Revzin 1981) was used to search for proteins binding to the different cell-type-specific promoter elements. I discovered that all of the elements described above are able to form specific DNA-protein complexes with unfractionated yeast extracts. The band shifts shown in Figure 3 were obtained with a crude extract originating from a $M A T$ a strain. One can therefore exclude interference or participation of $M A T \alpha$-derived proteins in the formation of these complexes. Similar results can be obtained with extracts from a/ $\alpha$ or $\alpha$ cells (data not shown), indicating that the presence of binding activity is not cell-type-dependent. Plasmids that contained the $\alpha$-specific oligonucleotide $M F \alpha 1$-A or a region of the $M F \alpha 1$ promoter encoding the two $\mathrm{P}^{\prime} \mathrm{Q}$ elements were able to compete for the protein or proteins binding to the 47-bp STE2 operator fragment (Fig. 4) and vice versa (data not shown). Quantitative comparison, however, indicates that the $\alpha 1$-dependent elements of the $M F \alpha 1$ promoter are weaker competitors than the STE2 probe, itself /data not shown), or the perfect palindrome of $M F \alpha 1$-C' (Fig. 4A). Nevertheless, these data also show clearly that both a- and $\alpha$-specific elements are able to bind the same factor in vitro, even in the absence of $\alpha 1$ protein. This is contrary to the report by Bender and Sprague (1987) (assuming that the binding activities described here and in that paper are equivalent). On the basis of primary experiments with the promoter of the STE3 gene (coding for the a-factor receptor), they claimed that $\alpha$-specific elements only bind PRTF in cooperation with $\alpha 1$. Although this may be correct for the STE3 promoter, perhaps $\alpha 1$ serves additional functions (other than recruitment of PRTF/ in the formation of an active transcription complex in connection with the $M F \alpha 1$ promoter.

The observation that PRTF is able to form a complex with the STE2 element suggests that PRTF binding is required for the activation of this a-specific element. As a consequence, one would predict that the mutated and transcriptionally inactive STE2-UAS47 fragment should be unable to bind the factor, as indicated by the reduction or absence of a band shift in the binding assay. 


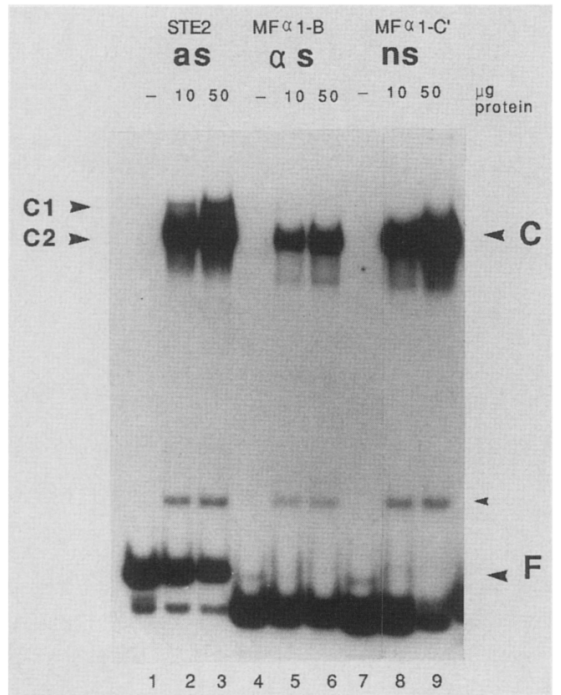

Figure 3. Band-shift assays using fragments containing the 47-bp STE2-UAS (lanes 1-3), the 23-bp MF 1 1-B (lanes 4-6), and the 19-bp MFo1-C' sequence (lanes 7-9). They serve as examples of an a, $\alpha$, and nonspecific UAS, as measured by the in vivo activation assay. $(C, C 1$, and $C 2)$ Complexes containing PRTF. C1 marks a complex containing the product of the STE12 gene (Errede and Ammerer 1989). It can only be observed with the 47-bp STE2 probe and then only at high protein concentrations and in unfractionated extracts. The unlabeled arrowhead indicates an activity that behaves highly irregularly in competition assays and does not bind to heparin-agarose under the conditions used (see also Figs. 3 and 4). (F) Positions of free probes.

This is indeed what one observes. As shown in Figure $5 \mathrm{~A}$, the mutations in the 47 -bp fragment lead to a significant decrease in the complex formation. The correlation between binding in vitro and activation in vivo supports a model in which PRTF or GRM participates in the activation of at least some a-specific genes (Bender and Sprague 1987; Kronstadt et al. 1987; Kronstadt and V.L. MacKay, pers. comm.).

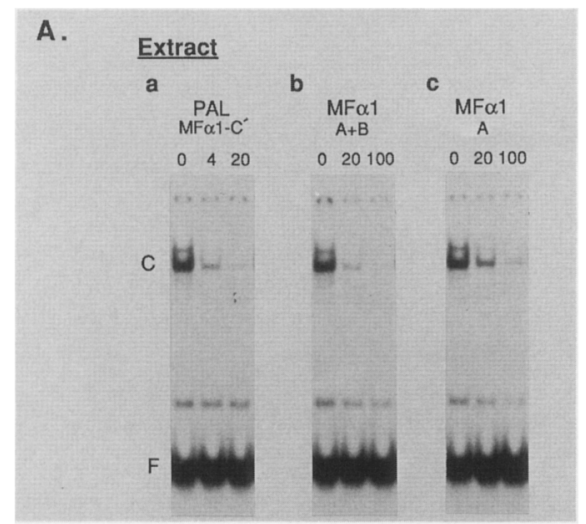

\section{Purification of PRTF/GRM}

To characterize P-box-binding proteins biochemically, I followed a strategy similar to the one described by Shore and Nasmyth (1987). An outline of the purification procedures is shown in Table 1 . Maximally, $5 \%$ of the binding activity can be detected in the flowthrough after yeast extract derived from a high-speed supernatant (S-100) was passed over a heparin-agarose column (Sorger and Pelham 1987; Sorger et al. 1988). Unlike the transcription factors described in these papers, HSF and RAP1, most of the P-box-binding material interacts very tightly with heparin-agarose and can be eluted only under conditions of high ionic strength. Small amounts $(<0.5 \%)$ of binding activity can be detected during elution of the column with a linear $50-600 \mathrm{~mm}$ ammonium sulfate (AS) gradient. This material does not elute as a single peak. It is distributed between 300 and $600 \mathrm{~mm}$ AS, and its concentration increases slightly toward higher AS concentrations (data not shown). I assume that material from these fractions constitutes the same factor, described below, that leaches from the column. On the other hand, it cannot be ruled out that these fractions identify a separate binding activity, as they were not characterized any further. Up to $80 \%$ of the initial binding activity was recovered after applying a subsequent gradient of $100-2000 \mathrm{mM} \mathrm{NaCl}$ to the heparin-agarose column. Fractions between 700 and 1100 $\mathrm{mM} \mathrm{NaCl}$ contain most of the P-box-binding activity, which elutes as a single peak. In a second chromatographic step, the pooled and dialyzed heparin-agarose fractions were loaded onto a nonspecific calf thymus DNA-Sepharose column. The binding activity was retained by the affinity medium only at $\mathrm{NaCl}$ concentrations lower than $150 \mathrm{~mm}$. It was eluted at $400 \mathrm{~mm} \mathrm{NaCl}$, using a gradient from $100-800 \mathrm{~mm}$. The pooled active fractions were brought to $100 \mathrm{mM} \mathrm{NaCl}$ and passed through a specific DNA-Sepharose (P-DNA-Sepharose) column containing concatenated oligomers of the $M F \alpha 1-\mathrm{C}^{\prime}$ sequence (Kadonaga and Tiian 1986). Surprisingly, the factor behaves on the specific column almost

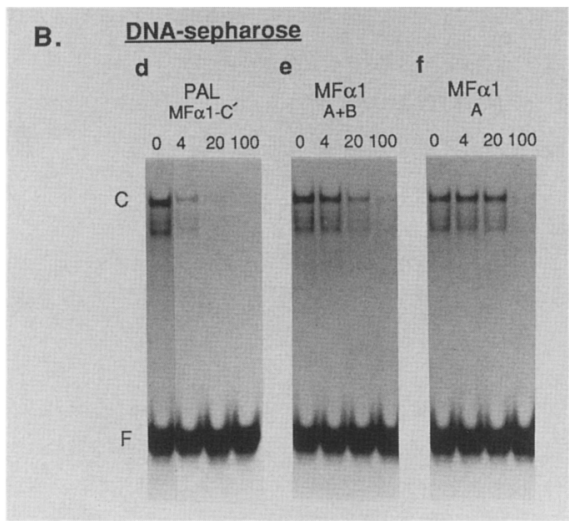

Figure 4. Competition between a- and $\alpha$-specific UAS elements for binding activity. (A) Results obtained with crude S-100 extract; $(B)$ results obtained with calf thymus DNA-Sepharose fractions. The probe is the 47-bp STE2-UAS fragment. Numbers at top of lanes give the molar excess of competitor binding sites cloned into pUC-derived vectors. The total amount of pUC-related DNA was kept at constant levels. The following competitors were used: the 19-bp $M F \alpha 1-\mathrm{C}^{\prime}$ sequence ( $a$ and $d$ ), a 24l-bp fragment of the $M F \alpha 1$ promoter containing block $\mathrm{A}$ and $\mathrm{B}(b$ and $e)$, and the 21-bp $M F \alpha 1-\mathrm{A}$ sequence $(c$ and $f)$. 


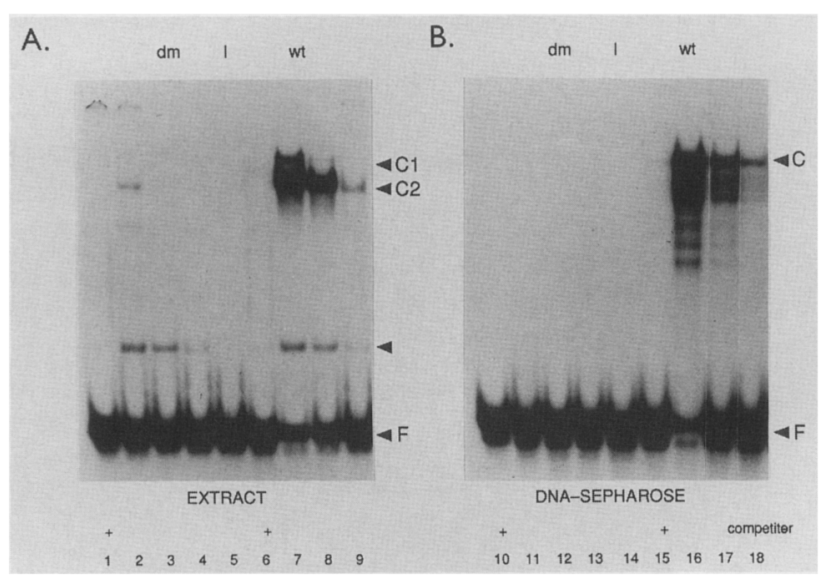

Figure 5. Effect of a double point mutation in the STE2-UAS on protein binding. The probe is the 47-bp STE2-UAS as the wild-type sequence ( $\mathrm{wt}$, lanes $6-9$ and $14-18$ ) or the double mutant (dm, lanes 1-5 and 10-13). Lanes 5 and 14 are controls containing free probes. $(A) \mathrm{Gel}$ shifts are obtained with different amounts of S-100 extract; $50 \mu \mathrm{g}$ of protein (lanes 1, 2, 6, and 7), $10 \mu \mathrm{g}$ (lanes 3 and 8 ), and $2 \mu \mathrm{g}$ (lanes 4 and 9). Lanes 1 and 6 contain 50-fold molar excess of $M F \alpha 1-C^{\prime}$ competitor. $(B) \mathrm{Gel}$ shifts with calf thymus DNA-Sepharose fractions: $0.5 \mu \mathrm{g}$ protein (lanes 10,11, 15, and 16), $0.1 \mu \mathrm{g}$ (lanes 12 and 17), and 0.02 $\mu \mathrm{g}$ (lanes 13 and 18).

identically as on the nonspecific DNA column. Binding is only achieved at $\mathrm{NaCl}$ concentrations below $150 \mathrm{~mm}$, and most of the activity elutes at salt concentrations of $\sim 400 \mathrm{~mm}$. This behavior of the factor posed the problem of how to purify it in the presence of proteins with high affinity for nonspecific DNA sequences.

As the purification strategy is mainly dependent on competition between nonspecifically and specifically binding proteins, it was advantageous to load the fractions in the presence of nonspecific competitor DNA poly[d(I-C)]. It also was necessary to pass the factor over the specific DNA affinity column up to three times before a homogeneous protein, as assayed by SDS-polyacrylamide gel electrophoresis, could be obtained (Tan et al. 1988; Fig. 1). Nevertheless, even after the first two passages, one can already detect a highly enriched protein on SDS-polyacrylamide gels with an apparent molecular weight of 40,000-50,000 (Fig. 6B). The migration of this protein is quite variable, depending on the percentage and polymerization conditions of the gel. Although other polypeptides seem enriched as well (Fig. 6B, lane 5), they are not consistently observed in all active fractions nor are they present after a third affinity purification step.

The P-box-binding activity was routinely tracked by a gel retardation assay. This assay does not provide information about the sequence specificity of the interaction, unless the signal can be competed by DNA containing the binding site. All signals using purified fractions and the 47-bp operator fragment of STE2 could be competed by the 19-bp P box $\left(M F \alpha 1-C^{\prime}\right)$. Additionally, it has been confirmed by DNase I protection assays that the factors present in the different fractions bind to the correct sequence (data not shown; Tan et al. 1988). One striking observation of the band-shift assays is that the pattern of the DNA-protein complexes changes after the heparinagarose chromatography (Figs. 5 and 6A). Even under conditions of probe excess, eight evenly spaced bands appear in assays using haparin-agarose calf thymus DNA-Sepharose, or P-DNA-Sepharose fractions. With S-100 extracts of similar activity, one is able to detect mainly one complex that migrates slightly slower than the largest complex formed with the purified fractions. Several explanations could account for these differences in band-shift pattern and will be discussed later. However, using the following criteria, it is likely that the protein(s) identified in the crude extract and the chromatographically purified fractions derive from identical gene products: (1) Quantitative comparison shows that both binding activities are within the same order of magnitude, as $80 \%$ can be recovered from the heparinagarose column (Table 1). (2) Competition experiments between the different mating-specific UAS fragments lead to similar results with both S-100 extracts and DNA-Sepharose fractions (Fig. 4B). (3) Binding of the purified factor to the STE2 operator DNA is affected by

Table 1. Purification of PRTF/GRM

\begin{tabular}{|c|c|c|c|c|c|c|}
\hline & $\begin{array}{l}\text { Volume } \\
\text { (ml) }\end{array}$ & $\begin{array}{l}\text { Protein concentration }{ }^{\mathrm{a}} \\
(\mathrm{mg} / \mathrm{ml})\end{array}$ & $\begin{array}{l}\text { Total protein } \\
\text { (mg) }\end{array}$ & $\begin{array}{l}\text { Total activity } \\
\left.\text { (units } \times 10^{3}\right)^{\mathrm{b}}\end{array}$ & $\begin{array}{l}\text { Specific activity } \\
\text { (U/mg) }\end{array}$ & $\begin{array}{l}\text { Yield } \\
\langle \%|\end{array}$ \\
\hline S-100 extract & 1800 & 60 & 108,000 & 200 & 0.54 & 100 \\
\hline Heparin-agarose & 400 & 10 & 4,000 & ND & ND & ND \\
\hline $\begin{array}{l}\text { Ammonium sulfate } \\
\text { precipitate }\end{array}$ & 175 & 2.4 & 420 & 140 & 333 & 70 \\
\hline Calf thymus DNA & & & & & & \\
\hline Sepharose & 64 & 3 & 190 & 60 & 315 & 30 \\
\hline $1 \times$ P Sepharose & 64 & ND & ND & 40 & ND & 20 \\
\hline $3 \times$ P Sepharose & 14.4 & $0.004^{\mathrm{c}}$ & 0.058 & 30 & $517 \times 10^{3}$ & 15 \\
\hline
\end{tabular}

aDetermined by Bio-Rad assay with bovine serum albumin as standard.

bOne unit of activity is defined as the amount sufficient to bind $1 \mathrm{ng}$ of a 47-bp fragment containing the STE2-P box under conditions of probe excess.

cEstimated by silver-stained gels (probably underestimated).

(ND) Not determined. 

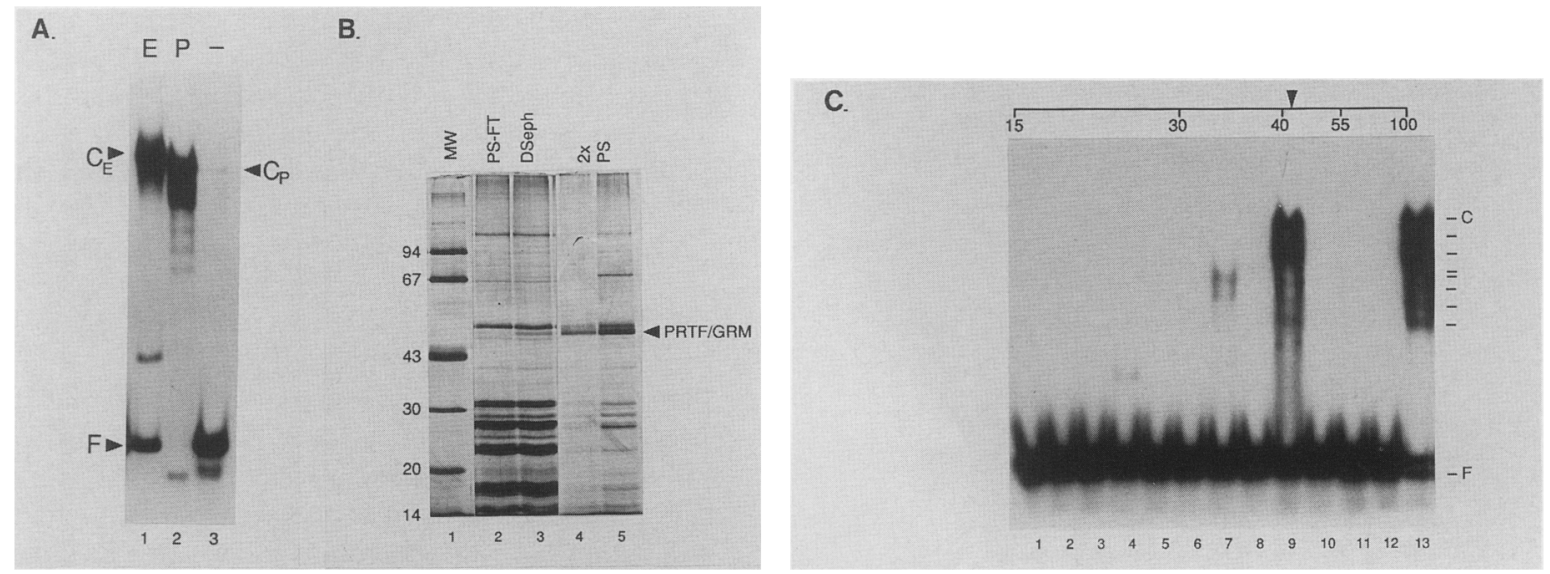

Figure 6. Purification of PRTF. (A) Differences in the pattern of DNA-protein complexes between crude extract and chromatographically purified fractions. The probe contained the $M F \alpha 1-C^{\prime}$ sequence. (Lane 1) The reaction with crude S-100 extract: (lane 2) affinitypurified protein $\left(1 \times\right.$ P-DNA-Sepharose); (lane 3) BSA. $\left(C_{E}\right)$ The position of complex obtained with extract $\left(C_{p}\right)$ position obtained with purified protein; $(F)$ position of free probe. $(B)$ Identification of PRTF on a SDS-polyacrylamide gel. Proteins were visualized by silver stain. (Lane 1) Molecular weight markers: $\alpha$-lactalbumin $\left(M_{\mathrm{r}} 14,400\right)$, trypsin inhibitor $\left(M_{\mathrm{r}} 20,100\right)$, carbonic anhydrase $\left(M_{\mathrm{r}} 30,000\right)$, ovalbumin $\left\{M_{\mathrm{r}} 43,000\right), \mathrm{BSA}\left(M_{\mathrm{r}} 67,000\right)$, phosphorylase b $(94,000)$; (lane 2) the flowthrough of the first specific DNA affinity column (PS-FT); (lane 3) calf thymus DNA-Sepharose fraction loaded on P-DNA affinity column (DSeph); (lanes 4 and 5) fractions containing the peak of P-box binding activity after a second round on the specific DNA affinity column $(2 \times$ PS). In this experiment PRTF migrated close to a protein of $M_{\mathrm{r}} 50,000$. Other proteins that seem enriched by the last purification step migrate at positions of $M_{\mathrm{r}}$ $\sim 68,000,38,000$ and 27,000. They are visible only in lane 5. (C) Equal amounts of calf thymus DNA-Sepharose fraction and a $1 \times$ P-DNA-Sepharose fraction were combined and separated on a SDS-polyacrylamide gel. Proteins were recovered from the gel slices, denatured with $6 \mathrm{M}$ guanidinium chloride, and renatured by diluting the samples with binding buffer. (Lanes 1-12) Band-shift assays from slices representing proteins from $M_{\mathrm{r}}$ 15,000-100,000. (Lane 13) The control band shift obtained with affinity-purified material. Part of the gel was stained and the band proposed as PRTF migrated at a position of $M_{\mathrm{r}} 43,000$, as indicated. (C) Position of main complex. Seven faster migrating complexes can be observed in lanes 9 and 13.

the double point mutation (Fig. 5B). (4) The purified factor is able to interact with $\alpha 1$ protein made from Escherichia coli cells (Tan et al. 1988), an observation also reported for crude extracts (Bender and Sprague 1987).

Two additional sets of experiments were performed to show that the binding activity is indeed represented by the $M_{\mathrm{r}} 40,000$ to 50,000 protein observed on SDS-polyacrylamide gels. The first involved extraction of the protein from the gel with subsequent reconstitution of DNA-binding activity. The second was an immunological approach showing that a protein of this size is present in the specific protein-DNA complex. About 5 $\mu \mathrm{g}$ of P-DNA-Sepharose-purified factor was combined with $50 \mu \mathrm{g}$ of calf thymus DNA-Sepharose fraction and separated on a preparative SDS-polyacrylamide gel. The gel was sliced into 12 bands representing proteins from $M_{\mathrm{r}} 16,000$ to 100,000 , and the proteins were eluted. After denaturation with $6 \mathrm{M}$ guanidine chloride and renaturation (Chodosh et al. 1986), the individual fractions were tested for binding activity (Fig. 6C). Three fractions exhibit DNA binding in the band-shift assay; however, only the fraction containing proteins between $M_{r} 40,000$ and 50,000 showed extensive binding activity. Around $5-10 \%$ of the original activity could be recovered. More importantly, only this fraction leads to the characteristic band-shift pattern of eight separate complexes, which was observed with the originally purified material.

Protein used for the production of antibodies was puri- fieci by just one P-DNA-Sepharose step and subsequent preparative SDS-gel electrophoresis. The eluted protein was injected into several mice and rats. Antisera obtained were specific in recognizing a protein of the correct size on Western blots. The protein was present in the calf thymus DNA-Sepharose fraction but not in the flowthrough of the specific DNA column (Fig. 7A). When antiserum was added to the binding assay, the protein-DNA complexes normally observed became even further retarded as a result of the formation of a triple complex of DNA, antigen, and antibody. This effect could not be seen with preimmune serum (Fig. 7B) or antiserum against a different yeast protein (data not shown), implying that the protein identified by the antiserum (further indicated as anti-PRTF antiserum) is indeed a component of the protein-DNA complex.

\section{Isolation of the gene encoding PRTF/GRM}

To characterize the protein identified by the antibody, a $\lambda$ gt11 yeast genomic library (Young and Davis 1984; a gift from D. Shore/ was screened with a $1: 200$ dilution of mouse anti-PRTF antiserum. I obtained 4 positive phage from a total of 300,000 recombinants. Two of these phage gave a much stronger signal than the others. One of them ( $\lambda$ prtf-C) was analyzed further and was eventually shown to encode a lacZ-ORF fusion product (Fig. 8). All of the positive phage proved to contain the same EcoRI-BamHI fragment. In the two weakly 


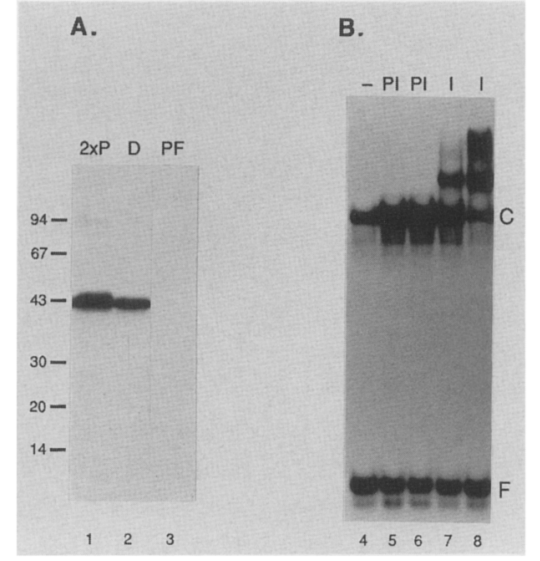

Figure 7. Characterization of mouse anti-PRTF antiserum. (A) Three protein fractions were analyzed by SDS-PAGE and Western blot using mouse antiserum and ${ }^{125}$ I-labeled protein $\mathrm{A}$. The following fractions were loaded: (lane 1) Protein purified by two consecutive runs on the P-DNA-Sepharose column $(2 \times \mathrm{P})$; (lane 2) $5 \mu \mathrm{g}$ protein of a calf thymus DNA-Sepharose fraction containing P-box-binding activity (D); (lane 3) flowthrough of the first run of a specific DNA affinity column containing $5 \mu \mathrm{g}$ of protein (PF). The signal detected on the autoradiograph corresponds exactly with the band identified as PRTF by silverstaining methods. $(B)$ The effects of the antiserum on the migration pattern of a PRTF-DNA complex $(C)$. The probe $(F)$ is a fragment containing the $M F \alpha 1-\mathrm{C}^{\prime}$ sequence cloned into the polylinker of pIC19R. The fragment was incubated with calf thymus DNA-Sepharose fraction without (lane 4) or in the presence of mouse serum (lanes 5-8). In lanes 5 and 6, complexes were formed with $1 \mu \mathrm{l}$ serum (at dilution of $1: 25$ and $1: 100$ ) derived from the animal prior to immunization (PI). Lanes 7 and 8 show the equivalent experiments with serum derived after immunization with PRTF (indicated as I).

reacting phage ( $\lambda$ prtf- $H$ and $\lambda$ prtf- $E)$, this fragment proved to be in the opposite orientation compared to the phage encoding the fusion product (Fig. 8). Using this fragment as a probe, I isolated several clones from a genomic yeast plasmid library. A common 3200-bp XhoI$B a m H I$ fragment that encompassed the open reading frame determined by phage $\lambda$ prtf-C was present in all clones and subcloned for sequence analysis. In Figure 9, $1800 \mathrm{bp}$ of the DNA sequence is shown. The sequence contains one long open reading frame encoding a protein of 286 amino acids. A gene disruption experiment that deleted the whole of the coding region revealed that the gene product is essential for survival of the yeast cell (data not shown).

\section{PRTF/GRM is encoded by the FUN80/MCMl gene}

A search of a data base revealed that the DNA sequence of the fragment characterized had already been published elsewhere as the FUN80 locus (Dubois et al. 1987b). The only notable difference between the two sequences is an additional nucleotide at position 965 in the sequence shown in Figure 9, which is missing at position 467 of the FUN80 sequence. This change results in a longer open reading frame, which now extends an additional $387 \mathrm{bp}$ to encode a protein of 286 amino acids instead of 157. I believe that this difference results from a sequencing error or cloning artifact. Quite recently, the DNA sequence of the MCM1 gene (Maine et al. 1984) has been published (Passmore et al. 1988), showing that MCM1 is allelic to FUN80. The MCM1 sequence concurs with my data, except for a minor difference in the $5^{\prime}$-flanking region. Therefore, the gene obtained by the immunological screen will be referred to further as MCM1 gene.

An important question is whether the MCM1 gene was just fortuitously cloned and sequenced (e.g., as a result of cross-reactivities with the antibody or as a member of a multigene family) or whether it indeed encodes PRTF/GRM. Recently, a genetic link between MCM1 and cell-type-specific expression has been established, as certain $\mathrm{mcm} 1$ alleles show $\alpha$-specific mating defects (Passmore et al. 1988). The additional observation that the transcription of $\alpha$-specific genes is reduced in such mutants suggested that this gene either encodes a component of PRTF, itself, or is involved in the establishment of the $\alpha 1-$ PRTF complex. I tried to obtain direct evidence for the equivalence of the MCM1 product and PRTF by taking two approaches. In the first experiment, I tried to overexpress the MCM1 gene with the GAL1 promoter (Johnston and Davis 1984) and looked for the accumulation of PRTF antibody-reactive material. One of the deletion end points obtained during the sequencing of the gene placed a HindIII site $116 \mathrm{bp}$ upstream of the open reading frame. This site was used to join the GAL1 promoter with the gene (Fig. 10A). The fusion was introduced into a centromere containing plasmid and transformed into a MATa strain. Transformants containing the fusion or a control plasmid were grown under noninduced conditions ( $2 \%$ raffinose) to late $\log$ phase and then transferred to medium containing galactose. After $4 \mathrm{hr}$, the cells were harvested and extracts were prepared for SDS-polyacrylamide gel electrophoresis. Proteins were analyzed on Western blots using mouse anti-PRTF serum. As shown in Figure $10 \mathrm{~B}$, lane 1 , there is a considerable increase in immunoreactive material in an extract from yeast containing the gene fused to the GAL1 promoter.

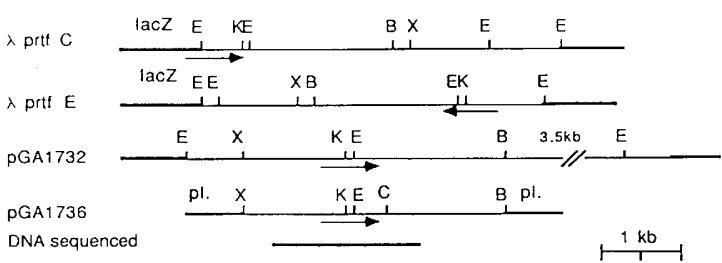

Figure 8. PRTF encoding plasmids and phage. Restriction maps of inserts containing the gene are shown. The insert of plasmid pGA1732 is cloned as partially cut Sau3A fragment into the BamHI site of the tet gene of the pBR322-derived vector. The bar indicates the area for which the DNA sequence has been determined. Restriction sites are as follows: (B) BamHI; (C) ClaI; (E) EcoRI; (K) KpnI; (X) XhoI; (pl) polylinker of pIC19H (Marsh et al. 1984). 


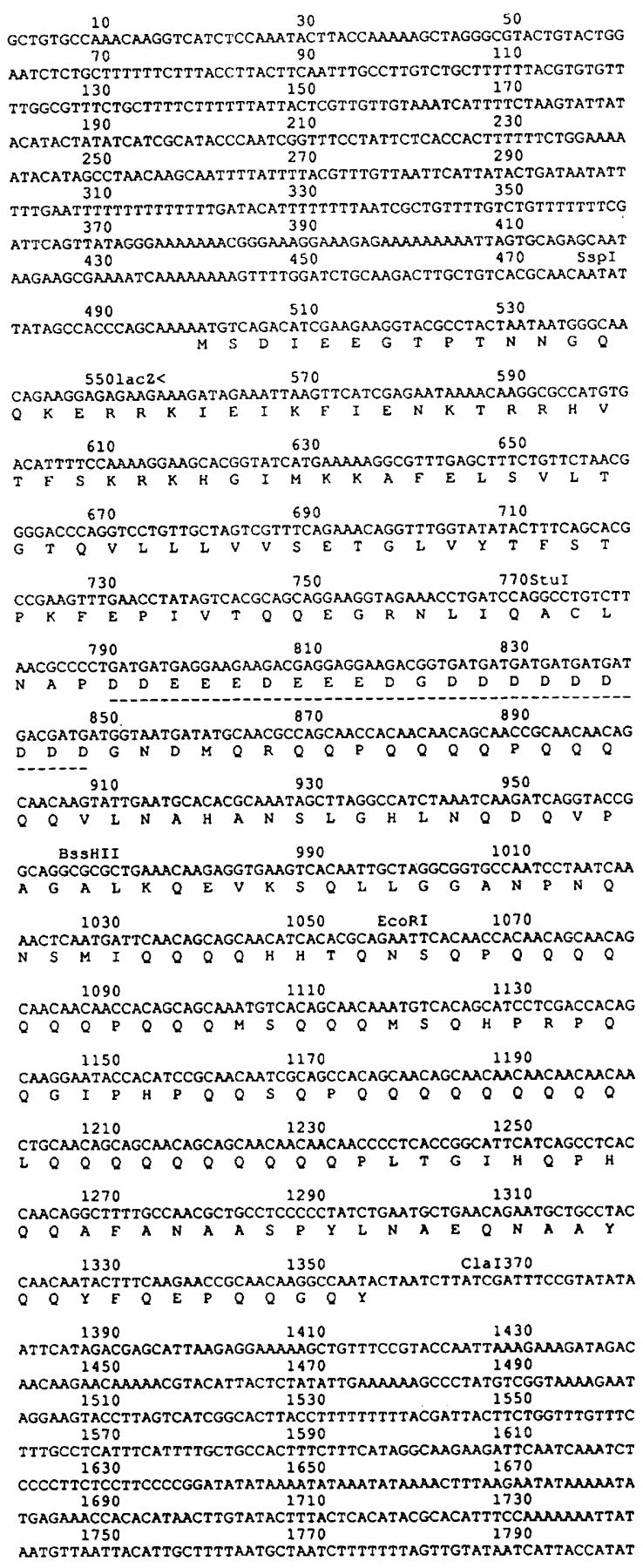

Figure 9. DNA sequence of the gene encoding PRTF activity. The sequence was determined by the chain termination method on both strands. Restriction sites relevant for the experiments described here are indicated. The point of fusion with the lac $Z$ sequence of $\lambda$ prtf- $C$ is shown at position $555(<)$. The negatively charged domain of the amino acid sequence is underlined.

In the second approach, I translated the open reading frame in vitro from RNA generated with T7 polymerase (Fig. 10A). The product obtained from the in vitro transcript should contain MCM1 with an amino-terminal extension of 8 amino acids generated by the initiation codon of the encephalomyocarditis (EMC) virus $\mathrm{P} 3$ gene (Parks et al. 1986) and the untranslated leader of the MCM1 gene. The translation products from a rabbit reticulocyte system were examined on a Western blot. The immunoreactive material comigrated with the affinity-purified product, and the protein species was enhanced by the GAL1-promoter construct (Fig. 10B, lane 4). In yeast cell extracts and in the in vitro-generated protein samples, one can detect an additional band migrating slightly slower than purified PRTF. This could be attributable to either cross-reacting material in the cell extracts or to post-translational modifications of the protein. The faster migrating band, which is quite dominant in the strain overexpressing the MCM1 gene, can best be explained as a degradation product of MCM1.

The MCMl proteins generated by in vitro translation (Fig. $11 \mathrm{~A}, \mathrm{C}$ ) were also tested in a band-shift assay. The product derived from full-length RNA produces two predominant complexes with the 47-bp STE2 fragment. The more intensively labeled band comigrates with the major complex found with purified product (Fig. 11B). A minor band comigrates with the fifth band of the additional trailing bands found with purified protein. I be-

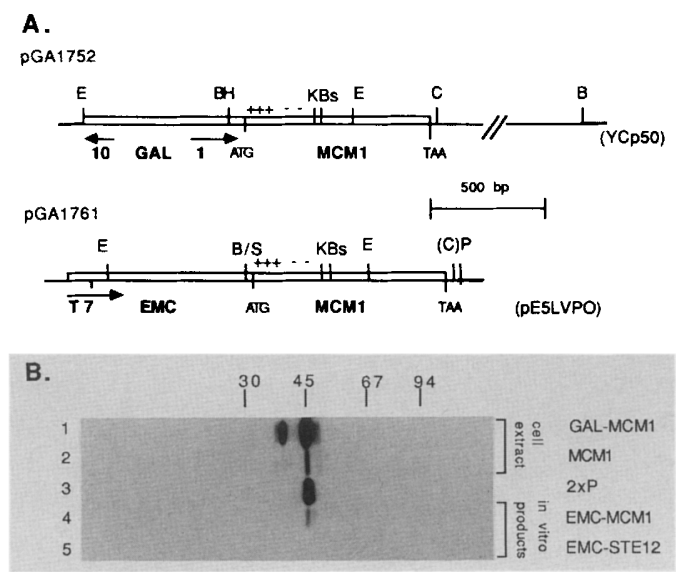

Figure 10. Expression of $M C M 1$ protein from gene fusions. $(A)$ The map of plasmid pGA1752 used for expressing the MCM1 gene under the control of the GAL1 promoter and of plasmid pGA1761, used for synthesis of MCM1 RNA in vitro using T7 polymerase. The following restriction sites are indicated: (B) BamHI; (Bs) BssHII; (C) ClaI; [(C)] ClaI-AccI fusion: (E) EcoRI; (H) HindIII; (K) KpnI; (P) PstI; (B/S) BalI-SspI junction; (S) StuI. $(B)$ SDS-PAGE and Western analysis of proteins extracted from yeast cells (lanes 1 and 2) and proteins synthesized in a rabbit reticulocyte lysate (lanes 4 and 5), using mouse anti-PRTF and protein A. Lane 3 contains affinity-purified PRTF plus BSA as carrier protein. Extracts used for lane 1 were made from yeast cells transformed with the GAL-MCM1 fusion plasmid; in lane 2, MCM1 was produced from the chromosomal copy. Yeast cells were grown to late log phase in medium containing $2 \%$ raffinose and galactose was added to $2 \%$ final concentration. Both lanes should contain the same amount of protein according to the intensity of the staining pattern obtained with Coomassie blue. Lane 4 was loaded with $10 \mu \mathrm{l}$ of a lysate with translated EMC-MCM1 RNA; lane 5 was loaded with the same amount of translation mixture derived from an EMC-STE12 construct. 


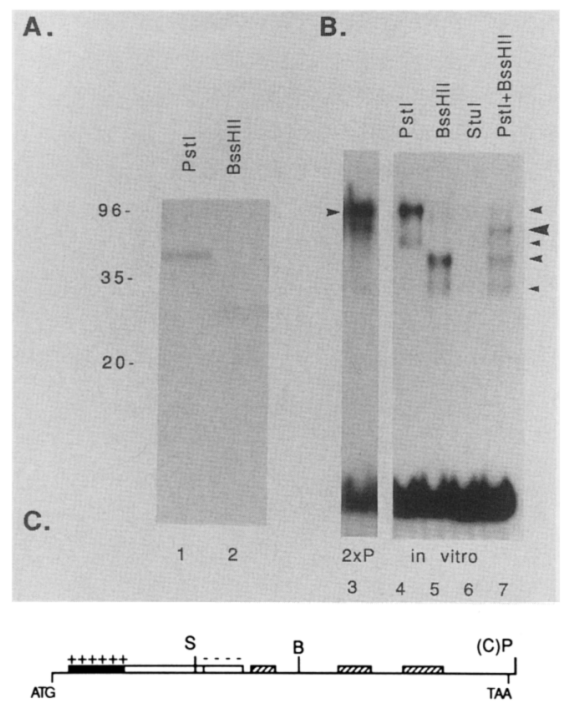

Figure 11. Gel shift experiments with in vitro-synthesized MCM1 protein. Plasmid pGA1761 was cut either with PstI, BssHII, or StuI. RNA was synthesized using T7 RNA polymerase. Proteins were synthesized in the presence of ${ }^{35} \mathrm{~S}$ or cold methionine. $(A)^{35}$ S-labeled products from PstI and BssHII RNA separated on SDS-polyacrylamide gel (lanes 1 and 2). (B) A band-shift assay using a $M F \alpha 1-\mathrm{C}^{\prime} \mathrm{P}$ box containing fragment and unlabeled translation products (lanes 3-7). Materials used for the assay were affinity-purified PRTF (lane 3); $0.5 \mu \mathrm{l}$ of rabbit reticulocyte lysate translating full-length EMC-MCM1 RNA (lane 4); translating RNA extending to the BssHII and StuI sites, respectively (lanes 5 and 6); translating a $1: 1$ mixture of full-length and truncated (BssHII) RNA (lane 7). The five arrowheads mark the position of the complexes found in the mixing experiment, with the complex proposed as hybrid between the two proteins indicated by the largest arrow. $(C)$ The MCM1translated region. Pluses $|+|$ above the solid bar indicate the presumptive DNA-binding domain; minuses $|-|$ the negatively charged amino acid stretch. The position of the polyglutimine repeats is represented by hatched bars. (S) StuI; $|\mathrm{B}| B s s \mathrm{HII}_{\text {; }}(\mathrm{P})$ PstI $;(\mathrm{C})$ the destroyed ClaI site.

lieve that the two signals represent a monomeric and dimeric complex of MCM1 (or oligomers of the form $n$ and $2 n$ ) for the following reason: A truncated version of the protein obtained from RNA that extends only to the $B s s \mathrm{HII}$ site at amino acid position 160 showed a faster migrating pattern in the gel shift assay. Coexpression of the truncated and complete products results in a pattern of five complexes (Fig. 11B, lane 7). The position of one of these complexes can be interpreted as the formation of a heterodimer, which is consistent with the hypothesis that MCM1 binds predominantly in an oligomerized state. In summary, these results clearly establish the MCM1 product as the DNA-binding component of PRTF.

\section{Interaction of MCM1 with MATa2 protein}

To establish that MCM1 is also responsible for GRM activity (Keleher et al. 1988), $\alpha 2$ protein was tested for its ability to bind to the STE2-UAS fragment in the presence or absence of the MCM1 product. For a source of $\alpha 2$, I used a protein that was purified from $E$. coli cells. As demonstrated in Figure 12, one cannot detect the formation of a specific complex between $\alpha 2$ and its target sequence using the gel retardation assay as described. However, under the same assay conditions, one can observe a complex formed with purified MCM1. If $\alpha 2$ protein is now included in this reaction, it causes a further shift of the MCM1/DNA complex. The formation of this slower migrating complex most likely indicates recruitment of $\alpha 2$ to the operator sequence. This interpretation is also supported by the observation that extracts from yeast cells overexpressing the MATa2 gene show a similar shift in the position of the PRTF/GRM complex (Fig. 12; Keleher et al. 1988). Identical results were obtained with MCM1 synthesized in vitro using a rabbit reticulocyte system (Fig. 12B). Therefore, MCM1 is not only the component of GRM that provides DNA-binding function, but it is also the peptide mainly responsible for the interaction with $\alpha 2$.

\section{Amino acid sequence of MCM1; similarities to other proteins}

On examination of the predicted amino acid sequence of

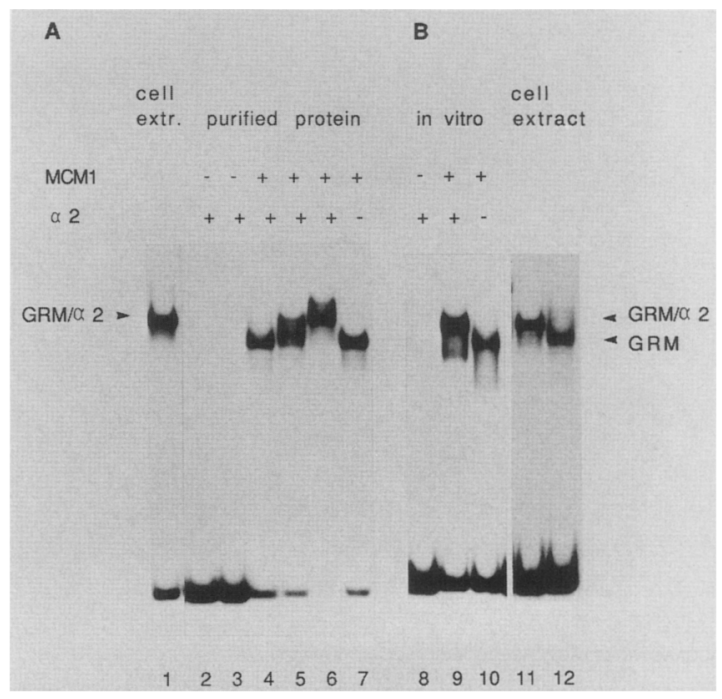

Figure 12. MCM1 is necessary for efficient binding of $\alpha 2$ to its operator. In this band-shift assay, a 97-bp fragment of the STE2 promoter containing the MCMl-binding site was used as a probe (Errede and Ammerer 1989). (Lanes 1 and 11) The position of the PRTF/GRM complex (indicated as GRM/ $\alpha 2$ ) of a yeast extract, in which $\alpha 2$ was present in high concentration as a result of the expression of the $\alpha 2$ gene from a strong promoter (Ammerer 1983). (Lane 12) Extract was used from a MATa strain to indicate the normal position of the GRM complex (to avoid complications of the pattern, the strains were also deleted for the STE12 gene). In all other lanes except were indicated, the binding assay was performed with highly enriched fractions of $\alpha 2$ protein derived from E. coli cells. (Lanes 2, 5, 8, and 9) 30 ng of protein; (lanes 3 and 4) $15 \mathrm{ng}$; (lane 2) $60 \mathrm{ng}$. (A) Affinitypurified MCM1 was added to the assay in lanes $4,5,6$, and $7 .(B)$ (lanes 9 and 10) $1 \mu \mathrm{l}$ was added from a rabbit reticulocyte extract in which full-length EMC-MCM1 RNA had been translated. 
MCM1, one can clearly identify four distinct regions of the protein. All of the domains show similarities with other proteins; however, the most striking ones are certainly found within the first two domains, which consist of a mainly positively charged amino terminus, followed by a stretch of hydrophobic residues. Over an area of 81 amino acids, one can find $69 \%$ identity with human SRF (c-fos serum response transcription factor) and 66\% identity with another yeast regulatory protein, ARGRI (or ARG80; Dubois et al. 1987a). By analogy to experiments with human SRF, it is very likely that the aminoterminal domains alone encode the DNA-binding motif and any surfaces that are involved in the oligomerization of the protein (Norman et al. 1988). Although a 160amino-acid product is still able to bind to a probe containing the $\mathrm{P}$ box, a protein that is truncated at amino acid 92 is inactive (Fig. 11B, lane 6) suggesting that the whole region of similarity with SRF may be important for DNA binding. A practically uninterrupted stretch of 20 negatively charged amino acid residues forms the boundary to the amino-terminal domains. This rather extensive acidic domain is followed by several stretches of glutamine-rich areas. Occurrences of these structures in other proteins and their possible functions have been discussed elsewhere (Passmore et al. 1988).

\section{Discussion}

The MCM1 product constitutes the main binding activity to the TTTCCTAATTAGGAAA motif

The specific question I tried to answer in this work was directed mainly toward the nature of the protein or proteins binding to the P box. I could show that the majority of the binding activity (as detected by band-shift assays) must be attributable to a single polypeptide. This polypeptide proved to be encoded by the MCM1 locus. Although, from the purification data alone one cannot exclude the existence of proteins with similar or identical DNA-binding specificity, it seems that such proteins have to be expressed at least an order of magnitude lower than MCM1. Along the purification of the binding activity, I made two observations that deserve some explanation. First, the chromatographic properties of the protein are very similar on the specific and nonspecific DNA columns. The binding of the protein to the affinity medium is highly sensitive to the salt concentration but independent of the particular DNA sequence. Therefore, one must assume that the ionic conditions primarily prevent protein-protein interactions le.g., dimerization), which are a precondition for specific DNA-protein interactions. Second, one can observe a qualitative change in the migration pattern of the protein-DNA complexes after the first chromatographic purification step. It is therefore possible that an as yet unidentified protein may participate in the complex found in the crude extract. In this context it is noteworthy that the binding activity observed in the crude extract also seems slightly less sensitive to the double point mutation than the activity found in the calf thymus DNA-Sepharose fraction (Fig. 5B). The loss of a polypeptide during the heparin-agarose step may easily account for the difference in the retardation between complexes formed in crude extract and purified fractions. Alternatively, a protein modification may be lost during the purification procedure. Neither possibility has been investigated as yet.

The appearance of distinct trailing bands in the bandshift pattern can best be explained by proteolysis at specific hypersensitive sites in the carboxy-terminal glutamine-rich repeats. If this is the case, one would expect that these repeats are not essential for the interaction with $\alpha 1$, as the faster migrating complexes are also retarded further by the presence of this protein (Tan et al. 1988). The only result inconsistent with the interpretation of the trailing bands as proteolytic artifacts is the observation of mainly one band on silver-stained SDSpolyacrylamide gels and on Western blots (although the latter could easily be attributable to a concomittant loss of epitopes recognized by the antibodies). As an alternative explanation to proteolysis, one could argue that different conformational states of the protein may lead to the peculiar band-shift pattern (e.g., by exposing or masking the negatively charged domain to different degrees).

\section{PRTF and GRM are the same protein}

It has been suggested that PRTF (defined as a P-boxbinding factor interacting with $\alpha 1$ ) and GRM (defined as a P-box-binding protein interacting with $\alpha 2$ ) are actually the same gene product(s) (Keleher et al. 1988). This assumption was based primarily on a competition experiment using a rather large fragment of an a-specific promoter (STE2) and an $\alpha$-specific UAS element (Bender and Sprague 1987). They showed that both fragments compete effectively for the same binding activity. The work reported in this paper, using relatively small binding sites and highly purified protein, confirms this result. In a previously published experiment, it could be shown that the affinity-purified protein is able to interact with $\alpha 1$ produced in E. coli cells (Tan et al. 1988). In analogous experiments, it was found that the affinity-purified binding factor, as well as the in vitro-synthesized products, is also able to interact cooperatively with $\alpha 2$ protein purified from E. coli cells. As a consequence, these results leave only the following conclusion: The MCM1 gene encodes the DNA-binding component of both PRTF and GRM. Additionally, the MCM1 gene product must provide surfaces that are involved in land probably are sufficient for) the interaction with the two regulatory factors $\alpha 1$ and $\alpha 2$. Therefore, this work presents, so far, the strongest evidence for the model proposed in Figure 1. Regarding this model, MCM1 also provides one of the best examples of how one protein can be involved in both the activation and repression of several target promoters. A similar functional diversity has been proposed for several developmentally important proteins such as Ultrabithorax $(U b x)$ and other homeotic gene products (Bienz and Tremml 1988). 
Cell-type independent targets for MCM1

It has been shown that the MCM1 gene encodes an essential function for growth of the yeast cell, as a deletion of the gene is lethal (Dubois et al. 1987b; Passmore et al. 1988). In its simplest interpretation, this result implies that other genes require MCM1 for transcription. A search through a DNA sequence data base revealed a sequence upstream of the $C D C 28$ gene and a sequence in the transposable element Tyl as possible candidates for MCM1-binding sites. Although CDC28 encodes an essential function, the importance of this sequence in the activation of the $C D C 28$ promoter has not been demonstrated. PRTF/GRM has been shown to bind to the target sequence in Tyl (B. Errede and G. Ammerer, unpubl.), but this transposable element does not appear to have any important function for the survival of the yeast cell.

\section{MCM1 interactions as a model system}

The binding site for the mammalian transcription factor SRF is very similar to the consensus sequence of the PRTF/GRM-binding sites (Hayes et al. 1988). It has been shown that a fragment containing this sequence is able to activate transcription in yeast. This fragment also competes effectively with the MCM1-binding site for binding activity in an in vitro assay (Hayes et al. 1988). As the DNA-binding domains of several transcription factors have been conserved over long evolutionary distances, it was anticipated that SRF and PRTF may also contain similar DNA-binding domains. This prediction has been verified, as MCM1 and the protein predicted from a SRF cDNA clone (Norman et al. 1988) share a domain with almost $70 \%$ identity in the amino acid sequence. Although the proteins diverge completely outside of this region, one is tempted to speculate about functional similarities between SRF and PRTF/GRM as well. In this regard, the main function of PRTF/GRM seems to be to provide a strong sequence-specific interaction with the target promoters, whereas the biologically important functions are mediated by the factors interacting with PRTF/GRM. In addition to the interactions with cell-type-specific regulators, there is some evidence that PRTF/GRM also cooperates with a protein that is an essential component of the pheromone-induced signal transduction pathway in yeast (Errede and Ammerer 1989). It is quite likely that growth-factorstimulated activation on mammalian promoters will follow similar principles.

\section{Material and methods}

\section{Oligonucleotides, plasmids, and probes}

The following oligonucleotides were kindly supplied by $T$. Smith at the Laboratory of Molecular Biology-MRC DNA synthesis facility. tcgaCTATTGAAGGACTAATTAGGAAAG (called $M F \alpha 1-\mathrm{B}$ ), tcgaTTGATGGCCTAATTAGGAAGG (called MF $\alpha 1$-A), tcgaTTTATTCCTAATTAGGAAA (called MFa-1$\left.\mathrm{C}^{\prime}\right)$, and their complementary strands, including an XhoI overhang: gatcTAAATTTCCTAATTGGGTAAGTACATGAT-
GAAACACATATG (called STE2-UAS47), gatcTAAATTTCGTAATTGAGTAAGTACATGATGAAACACATATG (called STE2-UAS47dm), gatcGATTGAAGTTTTTTCAACCATGTAAATTTCCTAATTGGGTAAGTAC (called STE2-UAS52), and their complementary oligonucleotides with a tcga overhang. The oligonucleotides were annealed with their complement and ligated either into the XhoI site of plasmid pLG $\Delta-178$ (Guarente and Hoar 1984) or the BglII and XhoI sites of plasmid pGA1696 (same as pGAl695 but reversed order of restriction sites; Sorger and Pelham 1987) to generate UAS-CYC1 promoter fusions.

Radioactive probes were made by primed synthesis of the STE2-UAS47 and its double mutant with the primer CATATGTGTTTC. If subcloned into pIC19 vectors (Marsh et al. 1984), the recognition sequences were cut out of the vector with EcoRI and the ends were filled in the presence of $[\alpha-32$ P]dATP. Plasmids containing the oligonucleotide sequences subcloned into the XhoI site of pIC19R were also used for competition assays. Additionally, a 241-bp fragment of the $M F \alpha 1$ promoter was obtained after a synthetic (SalI) had been added onto a 5 '-promoter deletion. The fragment contains the $M F \alpha 1$ sequence from position -445 to position -204 from the ATG and was cloned as a SalI-SspI fragment into pIC19R cut with SalI and NruI.

Plasmid constructions and DNA preparations were made according to standard procedures (Maniatis et al. 1982). For sequencing of the MCM1 gene, an XhoI-BamHI fragment of $\sim 3.2$ $\mathrm{kb}$ from one of the originally isolated plasmids was subcloned into $\mathrm{pICl} 19 \mathrm{H}$ cut with XhoI and BamHI, and ExoIII/S1 deletions were generated that contain a HindIII site at the end points. The sequence was determined by the chain-termination method using double-stranded template. The GAL1 promoterMCM1 fusion (pGA1752) was constructed using a 2.5-kb HindIII-BamHI fragment from the deletions generated at the $M C M 1$ gene and an EcoRI-HindIII fragment containing the promoter. The HindIII site upstream of the MCM1-coding region was at position -116 from the ATG (position 381 in Fig. 9). The GAL1-GAL10 promoter fragment was obtained by subcloning a BamHI-EcoRI fragment (Johnston and Davis 1984) into the vector pUC19 and deleting the polylinker from the BamHI site to the PstI site. Both fragments were combined in plasmid YCp50 cut with EcoRI and BamHI.

For in vitro production of MCM1, the 889-bp SspI-ClaI fragment of pGA1735 was transferred into plasmid pE5LVPO (Parks et al. 1986; kindly provided by M. Nicklin), cut with BalI and $A c c$ I to give plasmid pGA1761.

The plasmid used for high expression of $\alpha 2$ was similar to one described for expression of $\alpha 1$, called pAX $\alpha 11$ (Ammerer 1983). The Mat 2 gene was placed behind the $A D H 1$ promoter using a XhoI-HindIII fragment.

\section{$\beta$-Galactosidase and DNA-binding assays}

The activity of the different cell-type-specific UAS-CYC1lacZ fusions was determined in isogenic strains $\mathrm{JH} 1$ (MAT $\alpha$, leu2, ura3, trp1) and G2 (MATa, leu2, ura3, trp1, kindly provided by Gary McKnight). The cultures were grown in selective medium to a density of $5 \times 10^{7}$ cells $/ \mathrm{ml}$, and activity was determined as described by Breeden and Nasmyth (1987). Gel shift assays were performed essentially as described by Shore and Nasmyth (1987). Typically, 0.1-1 ng of probe was incubated with $50-100 \mu \mathrm{g}$ of crude extract or $0.5 \mu \mathrm{g}$ of calf thymus DNA-Sepharose fraction. In these reactions, $0.5-2 \mu \mathrm{g}$ of poly[d(I-C)] (Boehringer-Mannheim) or pUC19 was used as nonspecific competitor. Samples (final volume, 10-15 $\mu$ l) were incubated at $23^{\circ} \mathrm{C}$ in $50 \mathrm{mM}$ Tris/ $\mathrm{HCl}(\mathrm{pH} 7.5), 100 \mathrm{mM} \mathrm{NaCl}, 5$ 
$\mathrm{mM} \mathrm{MgCl}_{2}$, and $12 \%$ glycerol for $15 \mathrm{~min}$ and loaded on a nondenaturing $6 \%$ polyacrylamide gel $(40: 1)$ in $22.5 \mathrm{~mm}$ Tris, 22.5 $\mathrm{mM}$ boric acid, and $0.63 \mathrm{~mm}$ EDTA. In assays performed with highly purified material, nonspecific DNA was omitted and human insulin $(1 \mu \mathrm{g})$ or BSA $(6 \mu \mathrm{g})$ was used as carrier.

\section{Purification of PRTF/GRM and generation of antiserum}

The purification procedure followed the one described by Sorger and Pelham (1987) up to the heparin-agarose chromatography. The protease-deficient strain BJ2168 (MATa, leu2, trp1, ura3, prb1, pep4, prc1, gal2) was grown in YEPD to late log phase, using a 400-liter fermenter. The cell paste was broken in liquid nitrogen using a Waring Blendor, and the resulting powder was extracted at $4^{\circ} \mathrm{C}$ in breakage buffer $[200 \mathrm{mM}$ Tris$\mathrm{HCl}(\mathrm{pH} 8.0), 10 \%$ (vol/vol) glycerol, $10 \mathrm{mM} \mathrm{MgCl}, 1 \mathrm{~mm}$ DTT, $1 \mu \mathrm{M}$ PMSF, $0.5 \mu \mathrm{M}$ TPCK, and $0.02 \mu \mathrm{M}$ TLCK] in the presence of $400 \mathrm{~mm}$ ammonium sulfate. The suspension was centrifuged at $45,000 \mathrm{rpm}$ for $1 \mathrm{hr}$ in a Beckman type $45 \mathrm{Ti}$ rotor. The supernatant was precipitated with $0.35 \mathrm{~g} / \mathrm{ml}$ ammonium sulfate, centrifuged, and resuspended in $\mathrm{A} 0$ buffer $[50 \mathrm{~mm}$ Tris- $\mathrm{HCl} / \mathrm{pH}$ 8.0 ), $1 \mathrm{mM}$ EDTA, 10\% (vol/vol) glycerol, $1 \mathrm{mM} \mathrm{DTT}$, and protease inhibitors at one-tenth the concentration of the breakage buffer]. After extensive dialysis against A50 buffer (same as A0 buffer with $50 \mathrm{~mm}$ ammonium sulfate), the crude extract could be frozen in liquid nitrogen and stored at $-70^{\circ} \mathrm{C}$ without loss of activity. The dialyzed crude extract was loaded on a 1.5-liter heparin-agarose column and washed extensively with A50. A linear A50-A600 (identical to A0 buffer but $600 \mathrm{~mm}$ in ammonium sulfate) gradient was applied to the column, which eluted $\sim 70 \%$ of the bound protein. The column was subsequently washed with $\mathrm{A} 50$, and a second linear gradient from 0 to $2 \mathrm{M} \mathrm{NaCl}$ (4 liter) was used to elute the rest of the protein. The fractions containing binding activity were pooled and precipitated with ammonium sulfate as described above. The pellet was resuspended and dialyzed against A50N100 buffer (A50 buffer containing $100 \mathrm{~mm} \mathrm{NaCl}$ ). At this stage, a precipitate formed, which was removed by centrifugation without loss of binding activity. The supernatant was loaded onto a $100-\mathrm{ml}$ calf thymus DNA-Sepharose column and washed with A50N100 buffer. The column was eluted with either a 1-liter $100-800 \mathrm{~mm}$ linear $\mathrm{NaCl}$ gradient or a $400 \mathrm{~mm} \mathrm{NaCl}$ step gradient. Fractions containing the binding activity were diluted to $100 \mathrm{~mm} \mathrm{NaCl}$ with A50G buffer [A50 buffer containing 0.025\% $n$-octyl- $\beta$-(Sigma)]. Aliquots were preincubated with poly[d(I-C)] and applied to a $3-\mathrm{ml}$ sequence-specific DNA column. The column was eluted with $20 \mathrm{ml}$ of N400G. The fractions containing binding activity were pooled, diluted with 4 volumes of A50G, reloaded on the specific column in the presence of poly[d(I-C)], washed, and eluted with a N400G buffer. For some experiments (Tan et al. 1988), this procedure was repeated once more without loading the sample in the presence of competitor DNA.

The specific DNA column was prepared essentially as described by Kadonaga and Tjian (1986). The synthetic oligonucleotides tcgaTTTATTCCTAATTAGGAAA and tcgaTTTCCTAATTAGGAATAAA ( $300 \mu \mathrm{g}$ each) were annealed, phosphorylated, and ligated to form concatemers consisting of an average of seven monomers. These molecules were linked to $5 \mathrm{ml}$ of $\mathrm{CNBr}$-activated Sepharose CL-4B. The amount of coupled DNA was estimated at $70-80 \mu \mathrm{g} / \mathrm{ml}$ resin.

For the generation of antibodies, the active fractions of the first specific DNA column run were separated on a $15 \%$ SDSpolyacrylamide gel. The protein was recovered from the gel as described by Wilcox (1986). The protein bands were visualized with Coomassie Blue in $50 \%$ methanol; a band of $M_{r} 45,000$ was excised from the gel and eluted overnight in $1 \mathrm{ml}$ of A50 containing $0.1 \%$ SDS. The sample was filtered by centrifugation through a syringe plugged with siliconized glass wool. The protein was precipitated with 5 volumes of cold chloroform $\left(-20^{\circ} \mathrm{C}\right)$, and the pellet resuspended in TE7.5 buffer containing $0.1 \%$ SDS. The solution was emulsified with complete Freund's adjuvant and injected into six mice and two rats at $2-5 \mu \mathrm{g} /$ per animal. The animals were boosted after 4 weeks with the same amount of protein. Four mice and two rats responded to the injections.

\section{Protein analysis and immunological methods}

Samples for polyacrylamide gel electrophoresis were prepared as follows. Human insulin $(5-10 \mu \mathrm{g})$ was added as carrier to $10-200 \mu \mathrm{l}$ of column fractions, and the proteins were precipitated with ice-cold $10 \%$ trichloroacetic acid. The pellet was washed with cold acetone $\left(-20^{\circ} \mathrm{C}\right)$ and taken up in SDS sample buffer. After boiling, it was electrophoresed on a $15 \%$ SDS-polyacrylamide gel (Laemmli 1970) and silver-stained using a kit from New England Nuclear (NEF-982). Yeast cells, resuspended in breaking buffer in Eppendorf tubes were broken using glass beads and total protein was examined. An equal amount of $2 \times$ sample buffer was added before the extract was boiled and loaded onto the gel. Western analysis was performed as described (Towbin et al. 1979) with a dilution of $1: 500$ of mouse anti-PRTF antiserum. Immunoreactive material was visualized with ${ }^{125}$ I-labeled protein A (Amersham).

The screening for $\lambda g t 11$ clones encoding immunoreactive proteins was performed as recommended (Huynh et al. 1985). Antibody was used at a dilution of $1: 200$. Isolation and analysis of the phage DNA was done according to Maniatis et al. (1982).

\section{In vitro transcription and translation assay}

One microgram of restricted plasmid DNA was transcribed with T7 polymerase (a gift of M. Nicklin, Institute of Molecular Pathology, Vienna) without the addition of $m^{7} G T P$. The RNA was precipitated with $2 \mathrm{M} \mathrm{LiCl}$ and translated in a rabbit reticulocyte lysate (Promega L4210) in the presence of cold or ${ }^{35}$ S $] \mathrm{me}$ thionine. In band-shift assays, a maximum of $0.5 \mu l$ lysate was added to the probe.

\section{a2 protein}

Purified $\alpha 2$ protein was kindly provided by S. Tan and T. Richmond (Eidgenössische Technische Hochschule Zurich). The protein was expressed in $E$. coli, using a vector system very similar to the one described by Keleher et al. (1988). The $\alpha 2$ protein was purified almost to homogeneity (as judged by SDSgel electrophoresis and Coomassie Blue staining) by separation on an S-200 column followed by high-performance liquid chromatography (HPLC) ion-exchange chromatography (S. Tan and T. Richmond, pers. comm.). The percentage of active protein was not determined in this study.

\section{Note}

After this manuscript was submitted, two papers were published that come essentially to the same conclusions as those described here (Jarvis et al. 1989; Passmore et al. 1989).

\section{Acknowledgments}

I am greatly indebted to Kim Nasmyth for providing space and support in his laboratory. I also thank him for his continued 
encouragement and advice, without which this paper would never have been completed. I also thank David Shore and Peter Sorger for advice, assistance, and materials, Song Tan and Tim Richmond for a generous supply of $\alpha 1$ and $\alpha 2$ protein and a productive collaboration, Markus Zwickl and Andrea Burgstaller for performing in vitro expression experiments, Michael Primig for performing experiments with $\alpha 2$, and Clive Price and Beverly Errede for suggestions on the manuscript. Most of this work was conducted at the Laboratory of Molecular Biology (MRC, Cambridge) while I was a recipient of an EMBO longterm fellowship. Additionally, I acknowledge the support of the Medical Research Council and the Institute of Molecular Pathology, Vienna.

\section{References}

Ammerer, G. 1983. Gene expression in yeast with the $A D C 1$ promoter. Methods Enzymol. 101: 192-201.

Bender, A. and G.F. Sprague, Jr. 1986. Yeast peptide pheromones, a-factor and $\alpha$-factor, activate a common response mechanism in their target cells. Cell 47: 929-937.

-1987. MAT $\alpha 1$ protein, a yeast transcription activator, binds synergistically with a second protein to a set of celltype-specific genes. Cell 50: 681-689.

Bienz, M. and G. Tremml. 1988. Domain of Ultrabithorax expression in Drosophila visceral mesoderm from autoregulation and exclusion. Nature 333: 576-578.

Breeden, L. and K.A. Nasmyth. 1987. Cell cycle control of the yeast $H O$ gene: cis-and trans-acting regulators. Cell 48: 389-397.

Chodosh, L.A., R.W. Carthew, and P.A. Sharp. 1986. A single polypeptide possesses the binding and transcription activities of the Adenovirus major late transcription factor. Mol. Cell. Biol. 6: 4723-4733.

Dubois, E., J. Bercy, and F. Messenguy. 1987a. Characterization of $A R G R I$ and $A R G R I I I$ required for specific regulation of arginine metabolism in yeast. Mol. Gen. Genet. 207: 142148.

Dubois, E., J. Bercy, F. Descamps, and F. Messenguy. 1987b. Characterization of two new genes essential for vegetative growth in Saccharomyces cerevisiae: Nucleotide sequence determination and chromosome mapping. Gene 55: 265275.

Errede, B. and G. Ammerer. 1989. STE12, a protein involved in cell-type-specific transcription and signal transduction in yeast, is part of protein-DNA complexes. Genes Dev. 3: $1349-1361$.

Fields, S., D.T. Chaleff, and G.F. Sprague, Jr. 1988. Yeast, STRE7, STE11, and STE12 genes are required for expression of cell-type specific genes. Mol. Cell. Biol. 8: 551-556.

Flessel, M.C., A.J. Brake, and J. Thorner. 1989. The $M F \alpha 1$ gene of Saccharomyces cerevisiae: Genetic mapping and mutational analysis of promoter elements. Genetics 121: 223236.

Fried, M. and D.M. Crothers. 1981. Equilibria and kinetics of lac repressor-operator interactions by polyacrylamide gel electrophoresis. Nucleic Acids Res. 9: 6505-6525.

Garner, M.M. and A. Revzin. 1981. A gel electrophoresis method for quantifying the binding of proteins to specific DNA regions. Applications to components of the Escherichia coli lactose operon regulatory system. Nucleic Acids Res. 9: 3047-3060.

Guarente, L. and E. Hoar. 1984. Upstream activation sites of the $C Y C 1$ gene of Saccharomyces cerevisiae are active when inverted but not when placed downstream of the TATA box. Proc. Natl. Acad. Sci. 81: 7860-7864.
Hartig, A., I. Holly, G. Saari, and V.L. MacKay. 1986. Multiple regulation of STE2, a mating type-specific gene of Saccharomyces cerevisiae. Mol. Cell. Biol. 6: 2106-2114.

Hayes, T.E., P. Sengupta, and B.H. Cochran. 1988. The human c-fos serum response factor and the yeast factors GRM/ PRTF have related DNA-binding specificities. Genes Dev. 2: $1713-1722$.

Huynh, T.V., R.A. Young, and R.W. Davis. 1985. Constructing and screening cDNA libraries in $\lambda \mathrm{gt} 10$ and $\lambda \mathrm{gt} 11$. In $A$ practical approach series. DNA cloning(ed. M. Glover), vol. I, pp. 49-78. IRL Press, Oxford.

Inokuchi, K., A. Nakayama, and F. Hishinuma. 1987. Identification of sequence elements that confer cell-type-specific control of $M F \alpha 1$ expression in Saccharomyces cerevisiae. Mol. Cell. Biol. 7: 3185-3193.

Jarvis, E.E., D.C. Hagen, and G.F. Sprague, Jr. 1988. Identification of a DNA segment that is necessary and sufficient for $\alpha$-specific gene control in Saccharomyces cerevisiae: Implications for regulation of $\alpha$-specific and a-specific genes. Mol. Cell. Biol. 8: 309-320.

Jarvis, E.E., K.L. Clark, and G.F. Sprague, Jr. 1989. The yeast transcription activator PRTF, a homolog of the mammalian serum response factor, is encoded by the $M C M 1$ gene. Genes Dev. 3: 936-945.

Johnson, A.D. and I. Herskowitz. 1985. A repressor (MAT $\alpha 2$ product) and its operator control expression of a set of cell type specific genes in yeast. Cell 42: 237-247.

Johnston, M. and R.W. Davis. 1984. Sequences that regulate the divergent GAL1-GAL10 promoter in Saccharomyces cerevisiae. Mol. Cell. Biol. 4: 1440-1448.

Kadonaga, J.T. and R. Tjian. 1986. Affinity purification of sequence-specific DNA binding proteins. Proc. Natl. Acad. Sci. 83: 5889-5893.

Keleher, C.A., C. Goutte, and A.D. Johnson. 1988. The yeast cell-type-specific repressor $\alpha 2$ acts cooperatively with a non-cell-type-specific protein. Cell 53: 927-936.

Kronstadt, J.W., J.A. Holly, and V.L. MacKay. 1987. A yeast operator overlaps an upstream activation site. Cell 50: 369377.

Laemmli, U.K. 1970. Cleavage of structural proteins during the assembly of the head of bacteriophage T4. Nature 227: 680685.

Maine, G.T., P. Sinha, and B.K. Tye. 1984. Mutants of S. cerevisiae defective in the maintenance of minichromosomes. Genetics 106: 365-385.

Maniatis, T., E.F. Fritsch, and J. Sambrook. 1982. Molecular cloning: A laboratory manual. Cold Spring Harbor Laboratory, Cold Spring Harbor, New York.

Marsh, J.L., M. Erfle, and E.J. Wykes. 1984. The pIC plasmid and phage vectors with versatile cloning sites for recombinant selection by insertional inactivation. Gene 32: 481485.

Miller, A.M., V.L. MacKay, and K.A. Nasmyth. 1985. Identification and comparison of two sequence elements that confer cell-type-specific transcription in yeast. Nature 314: 598-603.

Nakayama, N., A. Miyajima, and K. Arai. 1985. Nucleotide sequences of STE2 and STE3 cell-type-specific sterile genes from Saccharomyces cerevisiae. EMBO J. 4: 2643-2648.

- 1987. Common signal transduction system shared by STE2 and STE3 in haploid cells of Saccharomyces cerevisiae: Autocrine cell-cycle arrest results from forced expression of STE2. EMBO I. 6: 249-254.

Norman, C., M. Runswick, R. Pollock, and R. Treisman. 1988. Isolation and properties of cDNA clones encoding SRF, a transcription factor that binds to the c-fos serum response 
element. Cell 55: 989-1003.

Parks, G.D., G.M. Duke, and A.C. Palmenberg. 1986. Encephalomyocarditis virus $3 \mathrm{C}$ protease: Efficient cell-free expression from clones which link viral $5^{\prime}$-noncoding sequences to the P3 region. J. Virol. 60: 376-384.

Passmore, S., G.T. Maine, R. Elble, C. Christ, and B. Tye. 1988. Saccharomyces cerevisiae protein involved in plasmid maintenance is necessary for mating of MAT $\alpha$ cells. J. Mol. Biol. 204: 593-606.

Passmore, S. R. Elble, and B. Tye. 1989. A protein involved in minichromosome maintenance in yeast binds a transcriptional enhancer conserved in eukaryotes. Genes Dev. 3: $921-935$.

Shore, D. and K. Nasmyth. 1987. Purification and cloning of a DNA binding protein from yeast that binds to both silencer and activator elements. Cell 51: 721-730.

Sorger, P.K. and H.R.B. Pelham. 1987. Purification and characterization of a heat shock element binding protein from yeast. EMBO I. 6: 3035-3041.

Sorger, P.K., G. Ammerer, and D. Shore. 1988. Identification and purification of sequence-specific DNA-binding proteins. In A practical approach series. Protein functions /ed. T. Creighton|, pp. 199-223. IRL Press, Oxford.

Strathern, J., J. Hicks, and I. Herskowitz. 1981. Control of cell type in yeast by the mating type locus: $\alpha 1-\alpha 2$ hypothesis. $J$. Mol. Biol. 147: 357-372.

Tan, S., G. Ammerer, and T.J. Richmond. 1988. Interactions of purified transcription factors: Binding of yeast MAT $\alpha 1$ and PRTF to cell-type-specific, upstream activating sequences. EMBO I. 7: 4255-4264.

Towbin, H., T. Staehlin, and J. Gordon. 1979. Electrophoretic transfer of proteins from polyacrylamide gels to nitrocellulose sheets: Procedure and some applications. Proc. Natl. Acad. Sci. 83: 7371-7375.

Wilcox, M. 1986. Cell surface antigens. In A practical approach series. Drosophila (ed. D.B. Roberts) pp. 243-274. IRL Press, Oxford.

Wilson, K.L. and I. Herskowitz. 1986. Sequences upstream of the STE6 gene required for its expression and regulation by the mating type locus in Saccharomyces cerevisiae. Proc. Natl. Acad. Sci. 83: 2536-2540.

Young, R.A. and R.W. Davis. 1984. Yeast RNA polymerase II genes: Isolation with antibody probes. Science 222: 778782 . 


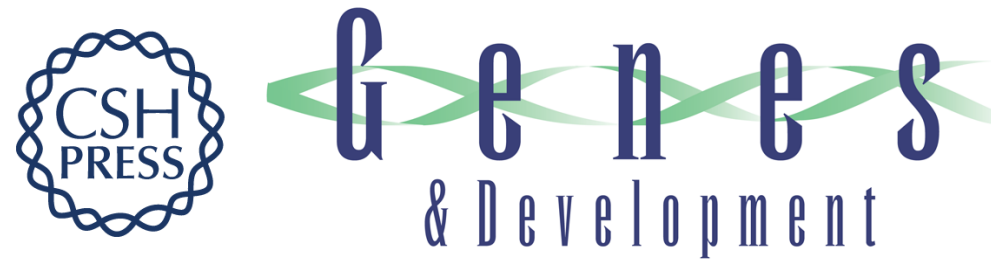

\section{Identification, purification, and cloning of a polypeptide (PRTF/GRM) that binds to mating-specific promoter elements in yeast.}

G Ammerer

Genes Dev. 1990, 4:

Access the most recent version at doi:10.1101/gad.4.2.299

References This article cites 41 articles, 16 of which can be accessed free at:

http://genesdev.cshlp.org/content/4/2/299.full.html\#ref-list-1

License

Email Alerting

Service right corner of the article or click here.

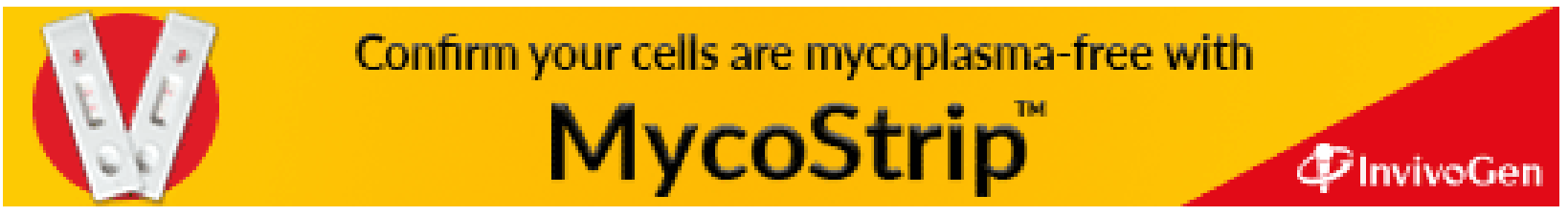

